\title{
National Renewable Energy Laboratory (NREL) Reports Increase in Durability and Reliability for Current Generation Fuel Cell Buses
}

NREL Team: Hydrogen Technology Validation, Leslie Eudy

Accomplishment: NREL recently reported an increase in durability and reliability for fuel cell systems demonstrated in transit service (first reported in July 2010).

Context: The transit industry provides an excellent test-bed for developing and optimizing advanced transportation technologies, such as fuel cells. In coordination with the Federal Transit Administration, the Department of Energy (DOE) funds the evaluation of fuel cell buses (FCBs) in real-world service. Under this funding, NREL has collected and analyzed data on nine early generation FCBs operated by four transit agencies in the United States.

NREL recently completed its evaluation of a current generation FCB design in use at three of these transit agencies. Beginning in November 2007, the fuel cell manufacturer (UTC Power) replaced the early version fuel cell power systems in all five buses with newer systems that were developed incorporating many of the lessons learned during prior operation. As of June 2010, two of the fuel cell systems accumulated a record number of hours without requiring repair or replacement of single fuel cells or cell stacks - one bus accrued more than 7,000 hours, and another more than 6,000 hours. These fuel cells continue to operate at rated power.

One measure of reliability/durability for the transit industry is miles between roadcall (MBRC). A roadcall is the failure of an in-service bus that requires it to be replaced on route or causes a significant schedule delay. Data collected by NREL show a significant increase in fuel cell related MBRC after the installation of the new fuel cell systems.

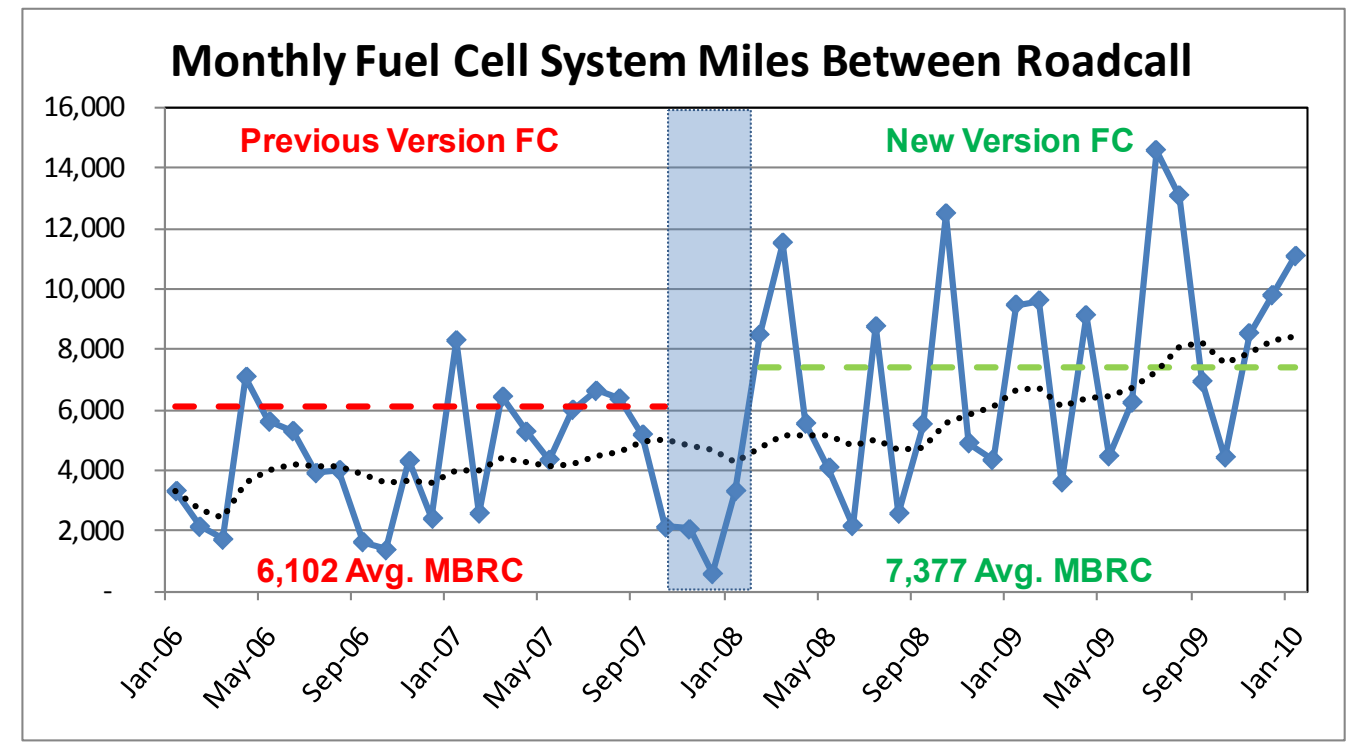

Reliability increased by $21 \%$ after the installation of the new fuel cell systems.

The black dotted line (trailing 12-month average) shows the upward trend over time.

The shaded area marks the timing of the new installations.

Applicable Department of Transportation Target: Achieve a 4-6 year (or 20,000-30,000 hour) durability for the fuel cell propulsion system. (For comparison, DOE has set a 2015 durability target of 5,000 hours for light-duty fuel cell electric vehicles.)

Significance of Accomplishment: Significant progress is being made toward demonstrating higher durability fuel cells for transit applications. Using fuel cells in transit buses can help accelerate the learning curve for the technology because of the high number of operating hours accumulated in short periods of time. Collecting detailed stack data on FCBs will help DOE validate the degradation of these systems over time. 